\title{
Assessing Nepal's military diplomacy: Neighborhood and beyond
}

\section{Gaurav Bhattarai}

\begin{abstract}
People often speculate that small countries hardly ever exercise military diplomacy since thelatterpresumethathardpowerinstruments, including security forces and coercion are the apparatus of powerful countries. Because of its geopolitical location between two bigger countries, Nepal has been successfully exercising military diplomacy in the course of history. Owing to the same fact, this paper aims at assessing Nepal's military diplomacy towards its immediate neighbors -India and China, and even beyond its neighborhood. In this paper, beyond neighborhood refers to the Nepali Army's role in United Nations peacekeeping missions in different conflictafflicted countries. Thus, the article concludes with a note that Nepali Army as an established institution of the country has reposed its exceptional capability of exercising the modern-day diplomacy at both levels - neighborhood and beyond.
\end{abstract}

Keywords: military diplomacy, India, China, UN Peacekeeping, neighbourhood

\section{Introduction}

Diplomacy is all about managing relations among states. It is the communication systems of the international society, as an attempt to promote international negotiations, whether concerning inter- or intra-state conflicts (Berridge, 2000, pp.1-3). But, there is no universally accepted definition of what constitutes military diplomacy or defense diplomacy. By its broadest definition, almost every externally-oriented military activity can be considered military diplomacy, as it would constitute an extension of international policy (Jaishankar, 2017). Precisely, military force is a true political instrument, a continuation of political intercourse, carried on with other means (Clausewitz, 1976, p. 87).Still, military diplomacy can be defined as a set of activities in operation by the representatives of the defense department, as well as other state institutions, aimed at pursuing the foreign policy interests of the state in the field of security and defense policy, and whose actions are based on the use of negotiations and other diplomatic instruments. Military diplomacy differs from gunboat diplomacy or coercive diplomacy (Pajtinka, 2016, p. 1).

Military diplomacy as such performs several basic functions. First, gathering and analyzing information on the armed forces and the security situation in the receiving state. Secondly, promotion of cooperation, communication and mutual relations between the armed forces of the sending and the receiving state. Thirdly, organization of working visits of representatives of the defense authorities and of peaceful stay of the military units of the sending state in the receiving state. Fourthly, support of business contracts with arms and military equipment between the sending and the receiving state. Lastly, representation of the sending state and its armed forces at official ceremonies and other events in the receiving state (Pajtinka, 2016, p. 1). 
Military diplomacy is a specific field of diplomacy, which focuses primarily on the pursuit of foreign policy interests of the state. Still, in the theory of international relations, and specifically within diplomatic science, military diplomacy has received much inadequate attention in comparison to public diplomacy, economic diplomacy, Mega-diplomacy, among others. Equally, in the domain of security studies, the military diplomacy is not a widely studied subject. In practice, the field of military diplomacy often tends to be closely linked with the intelligence activities of military intelligence. In many cases, there are a limited scholarship in military diplomacy, because the concerned authorities would maintain restricted to the classified materials in the field (Pajtinka, 2016, p. 1).

\section{Military diplomacy of Nepal: Retrospect and prospect}

For centuries, Nepal, has been diligently involved in military diplomacy. The Rana regime, which lasted in Nepal from 18461951, had strong bonds with the British. During the Indian Sepoy Mutiny of 1857-58, Nepal's Prime Minister Jung Bahadur Rana himself commanded a contingent of Nepali soldiers to assist the British, eventually commencing a tradition of Nepali military assistance to the British Empire. During the Rana regime, the Nepali Army (NA) remained strategically vital to the British Empire. It was very hard for East India Company forces to tackle the rebellion in the beginning. A Nepalese soldier at the front has been quoted as saying: "This war will soon be over. Jung Bahadur is going to march down to Lucknow with his army....He is our prime minister and commander-in-chief in Nepal. He offered to bring an army down to help you English two months ago, and now the government has accepted his offer" (Adhikari, 2015).

Later, Nepal aided the Young husband expedition to Tibet in 1903-1904. Chandra Shumsher, who had recognized British supremacy in much the way Jung Bahadur had, understood Nepal's relationship with Tibet no longer had the same importance as it did earlier. Thus, he offered Lord Curzon, the Nepali troops for the 1904 Young husband expedition. A year before the Young husband expedition, Chandra Shumsher had met Curzon at the Coronation Durbar. A few days after the meeting, Curzon reveals that:

We believe that the policy of frank discussion and co-operation with the Nepalese Durbar would find them prepared most cordially to assist our plans [in Tibet]. Not the slightest anxiety has been evinced at our recent forward operations on the Sikkim frontier; and we think that, with judicious management, useful assistance may confidently be expected from the side of Nepal...the Maharaja is prepared to co-operate with the Government of India in whatever way may be thought most desirable. (Mulmi, 2017)

Unforgettably, Nepal assisted the British government during the World Wars. This long history established military diplomacy as a major technique for Nepal's diplomatic relations. Also, Nepalis have a long history of engaging in foreign battles. In particular, the Nepali Army is renowned for their martial culture around the world (Amatya, 2018). More than 200,000 Nepali men participated in the Second World War on various fronts, at a time when the call for total independence 
in the subcontinent had reached far and wide (Mulmi, 2017).

Historically, Nepal's relations with its neighbors were determined by war and military affairs (Amatya, 2018). Now, there is a shift in Nepal's military diplomacy. At present, Nepal is increasing its military outreach to China. Even in 1989, when India had imposed a blockade on Nepal, the real reason for the blockade was that the government of Nepal had purchased weapons from China. Within a few years the Panchayat regime fell apart and multiparty democracy was installed in Nepal. In 2005, Nepal's King Gyanendra had also purchased weapons from China - a few years later he was deposed and Nepal was turned into a republic. Clearly, Nepal's efforts to enhance military relations with China have always sparked India's concerns, as New Delhi resents to the 1962 Sino-Indian War (Amatya, 2018). Nepal still continues to conduct joint military drills with India, with the latest being Surya Kiran XIII, which was held in June 2018. However, Nepal has also started military drills with China, with gives an entirely new image to Nepal's military diplomacy. In fact, Nepal recently backed out from a new joint military exercise in India planned for BIMSTEC states but continued its military drill with China, in Sichuan province (Amatya, 2018).

\section{Military diplomacy: Neighborhood and beyond}

Initiating Nepal's entry into different multilateral forums, King Mahendra, particularly after the 1962 India-China War, started reaching out to western countries for military assistance (Bhattarai, 2019). Western countries, mainly the US and the UK, responded positively to Mahendra's request for military assistance, and in 1964,
Nepal signed an agreement with the US, under which the Americans agreed to provide logistic support to the then Royal Nepali Army. Subsequently, the UK also started providing some military assistance to Nepal. India was already a major defense supplier to Nepal. Since 1950, Nepal and India have also been awarding the Army chiefs of each other the honorary rank of General in recognition of the harmonious relationship between the two armies. Three countriesIndia, the US and the UK - have long been Nepal's major defense partners, in terms of grant and sale, and have helped meet the requirements of the Nepali Army. But in the last three decades, there have been many changes in Nepal's defense cooperation. China has emerged as another major defense partner. Recent engagements between the two countries suggest China is all set to overtake Nepal's traditional defense partners (Bhattarai, 2019). Since the establishment of diplomatic relations between Nepal and China in 1955, the armies of the two countries have had cordial ties. Although Nepal and China signed an understanding on military cooperation in 1988, bilateral defense cooperation gained momentum mainly after King Gyanendra's royal takeover in 2005, and particularly after the abolition of the monarchy in 2008. For instance, on 24 Oct 2005, China pledged military assistance worth $\$ 989,000$ to Nepal, primarily to curb the Maoist insurgency. Between 2001 and 2005, the Nepal government also purchased military hardware from India, the US, the UK and Belgium to fight the rebels. But after the 2005 royal takeover, India, the US and the UK suspended their military aid to Nepal, demanding the restoration of democracy. The NA faced a shortage of military hardware to be sent to its peace missions abroad. In order to address its security interest in Nepal 
after the abolition of the monarchy, China adopted a policy of accelerating collaboration with Nepal's security forces. Officials from China's People's Liberation Army (PLA) started cultivating relations with Nepal's defense minister and army chief-something which continues to date. In June 2017, China handed over the National Armed Police Force Academy, which it built, to the Nepal government. In the handover ceremony, then Chinese Ambassador to Nepal Yu Hong said, "China is always willing to conduct pragmatic cooperation with Nepal in the field of talents, development and national security." Even before 1990, both Nepal and China had made efforts to enhance military collaboration, but those moves were opposed by India. In 1989, Nepal bought various military weapons from China - much to the chagrin of India, which argued that the purchase goes against the spirit of the 1950 Peace and Friendship Treaty. After the restoration of democracy in 1990, during the visit of interim Prime Minister Krishna Prasad Bhattarai to New Delhi, Indian officials asked him why the Nepal government purchased weapons from China. "Because we got them cheap and India did not meet all our requirements" (Bhattarai, 2019). Bhattarai reportedly told the Indian officials. After 1990, the defense collaboration between Nepal and China did not gain much momentum. However, Nepal continued to convince. India that it has the right to purchase military hardware from third countries. Along with regular military assistance from China, it would be worthwhile to discuss some vital developments that contributed to increased military cooperation between the two countries in the past decade (Bhattarai, 2019).

After the first Constituent Assembly (CA) elections in 2008, then Defense Minister
Ram Bahadur Thapa signed an agreement with China on military assistance worth $\$ 2.6$ million for the modernization of the NA in December 2008. After that, Chinese military officials, including the PLA chief, have continued to visit Kathmandu. A close analysis of trends shows that soon after the formation of a new government in Nepal, either China invites our defense minister for a visit or high level Chinese officials come to Kathmandu. In the case of the NA chief, there is a tradition of visiting India first after assuming office. Another turning point, according to observers, is the Indian blockade in 201516. General Rajendra Chettri reportedly was in a great quandary prior to his maiden visit as Chief of the Army Staff (COAS) to India. In line with a long tradition, he was invited to receive the title of the Honorary General of the Indian Army. But, since India had laid a siege on Nepal by imposing an economic blockade at that time, visiting India then was excruciatingly difficult to justify back home. General Chhetri however, saw it as a rare opportunity to hold direct talks with various constituencies in India to end Nepal's predicament. He consulted the then Nepali Prime Minister, who gave him a nod to proceed. It was, of course, a genuine undertaking from the part of COAS but that was ultimately paid off. The economic sanctions were still in effect for which he had embarked on a national mission but it was eventually lifted just a day before his arrival back in Kathmandu. According to some of the reports, prior to his visit, General Chettri had already quietly dispatched his military emissary to Delhi. A team comprising of two of his most trusted aides, including NA's Director General of Military Operations accompanied by one of the Colonels, in efforts to persuade their Indian counterparts towards a propitious resolution, reportedly 
set up a camp in the Indian capital for ten days and met with civilians and military brass and apprised them of dire consequences of the Indian economic embargo. Reportedly, the Indian Army was very receptive to NA's reasoning and rendered unequivocal support to the two senior Nepali officers in their mission. The Indian Army facilitated all the dialogues with other civilian counterparts in the Indian establishment and buttressed the NA's position. When the political realms of both countries collided, it was the militaries that were conciliatory and played a uniting role (Thapa, 2016). In the same way, relationship with the government of China, is another significant endeavor that the Nepali Army has made in recent years.

Two vital developments in 2017 deepened the military cooperation between Nepal and China. After a long hiatus, Chinese Defense Minister and State Councilor Chang Wanquan paid a three-day visit to Kathmandu in March. He announced a grant assistance of $\$ 32.3$ million to Nepal, to be spent on building Nepal's capacity to deal with natural calamities and purchasing equipment for Nepali Army peacekeepers deployed in conflict-affected areas. In the same year, the armies of the two countries conducted the first-ever joint military drill, paving the way for further collaboration. After the formation of the new government led by Nepal Communist Party (NCP) Chair KP Sharma Oli, Deputy Prime Minister and Minister for Foreign Affairs Ishwor Pokhrel visited China in October 2018. During the visit, Pokhrel and Chinese State Councilor and Defense Minister Wei Fenghe signed a Memorandum of Understanding (MoU) to consolidate relationships between two countries through their military institutions. "Minister Pokhrel mentioned the importance of military co- operation in military training, hardware in humanitarian and disaster management, and medical equipment and peace-keeping operations, and requested for Chinese support in establishing Defense University in Nepal," reads a press release issued by the Nepali Embassy in Beijing after the visit (Bhattarai, 2019). In respect to the agreement, China increased its military support to Nepal by 50 percent to strengthen Nepali Army's capability in disaster management and to better equip Nepal's UN Peacekeeping missions. China also announced an assistance worth RMB 150 million (Rs 2.53 billion) for the NA for the next five years (Bhattarai, 2019). But the Chinese military influence should be taken for larger context of the Science of Military Strategy unveiled by China in 2013, which is directed to developing a modern and capable military. China has since been assertive in all areas of foreign policy, including military diplomacy.

Between Nepal and China, bilateral military cooperation started in 1988. Nepal purchased military hardware, such as anti-aircraft guns, medium range SSM, among others in 1989. Soon after the royal takeover in 2005, China pledged military assistance of $\$ 989,000$ to Nepal to fight the Maoist insurgency. In December 2008, Nepal and China signed an agreement on military assistance worth \$ 2.6 million for the modernization of the Nepali Army. In 2009, China agreed to provide military aids worth 20.8 million Yuan (approximately Rs 220 million). In 2011, during his visit to Nepal, then Chinese Army Chief Chen Bingde announced military aid of $\$ 7.7$ million for the Nepali Army. In June 2013, Nepal and China agreed to construct the National Armed Police Force Academy during Chinese State Councilor Yang Jiechi's visit to Kathmandu. In 2017, 
China pledged an assistance of $\$ 32.3$ million to the Nepali Army Also, in 2017, Nepal and China began the first ever joint military drill, which was a major turning point in bilateral defense cooperation. In October 2018, China announced to provide an assistance worth RMB 150 million (Rs 2.53 billion) to the Nepali Army for the next five years (Bhattarai, 2019).

Acceptance of military assistance from friendly neighboring countries to the Nepali Army has played a significant role in keeping bilateral and military-to-military relations intact and active (Khatri, 2017). The level and volume of military assistance from neighbors along with the UK and the, especially after the post-Monarchy period in 2008 and postearthquake of 2015 in Nepal. The level of military assistances from the People's Liberation Army (PLA) of China has gone up after the Chinese Defence Minister and Sate Councilor General Chang Wanquan paid a three-day official visit to Kathmandu during 23-25 March, 2017. General Chang's was the first defense ministerial visit since the two countries established diplomatic relations in 1955 (Khatri, 2017). Chang's visit to Kathmandu saw PLA extending a grant assistance of USD 32.3 million to the NA for strengthening NA's capacity to deal with natural calamities and providing equipment for the United Nations peacekeeping missions. The grant assistance was 10 times higher than the China's previous military assistance to the NA before the post-Monarchy period. The visit of Chang had taken place on the eve of the first ever joint military exercise entitled, 'Sagarmatha Friendship' which was held on 16 April 2017 in Kathmandu. In 2011, China had signed an agreement for providing military aid to the tune of USD 7.7 million to the NA when the Chinese Army Chief
General Chen Bingde made his visit to Nepal in 2011. Besides financial assistance, the PLA has also increased the number of war college seats and National Defence Course (NDC) quotas for the NA officers. The current ratio of Chinese to the NA personnel in China's War College short term training programmes is around 4:1 (Khatri, 2017). The military assistance has become a strategic step of military/defense diplomacy between any two countries. Recently, during the official visit of China by Chief of Army Staff Purna Chandra Thapa, a protocol of signing was held on June 19 to receive an assistance of RMB 150 million over a period of next five years for humanitarian and disaster relief equipment. The protocol signing was held as per the agreement reached on October 27, 2018 during Deputy Prime Minister and Defense Minister Ishwor Pokharel's official visit to China. The agreement was inked between Chinese State Councilor Wei Fenghe and DPM Pokharel. The PLA had provided a total of 118 million RMB assistance to Nepal during the time of earthquake in 2015. The Chinese supports to Nepal and the earthquake victims include medical equipment, mobile field hospitals, and tents. There was no any military assistance from China in the year 2016. In the year 2017, China had agreed to provide 230 million RMB, which the NA would have received by the end of 2019 (Khatri, 2017). Similarly, in the year 2018, China had provided materials and equipment worth 150 million RMB that include mechanic bridges, vehicles, rescue kits and explosive ordnance disposal (EOD). Nepal has also been receiving supports from friendly countries beyond the immediate neighbors.

The U.S had provided mainly four Acrow bridges in the year 2014 that continues to date 
in Jitpur of Bara, Jure of Sindhupalchowk, Thankot bordering Kathmandu and Dhading districts (Khatri, 2017). Subsequently, in the year of earthquake in 2015, the U.S. government had provided mainly heavy vehicles, generators worth USD 3.67 million, radio sets worth USD 1.6 million, disaster related rafts and motorboats worth USD 245,000 and USD 1 million assistance for constructing one hospital for Birendra Peace Operation Training Centre of Dhulikhel in 2016 and explosive ordnance disposal worth USD 82,845 in 2018. Similarly, India's military assistance to Nepal is based on both loans and grants in a ratio of 60-40. If India provides any arm logistics, the NA has to bear 40 per cent of its total cost. NA had to pay Rs. 3.21 billion of loans to the Indian government or Indian Army as per the record of 2010 (Khatri, 2017). But usually, such due amount has a trend of receiving waivers from India based upon two nation's bilateral talks and agreements (Khatri, 2017). India's military assistance level and its mode of assistance are different from that of China and the U.S. As mentioned in the 1950 India-Nepal Treaty of Peace and Friendship, the Nepal government has been purchasing arms and ammunition only from India till date. In 2015, Nepal had purchased and received some military weapons, including binoculars from India. Nepal purchased and received grants in the forms of weapons and ammunition and military vehicles in 2017 and 2018. In 2019, NA got over 50 light vehicles from the Indian government (Khatri, 2017). Annually, the level of Chinese military assistance to NA is on rise by over 50 per cent. China is the only country which has been providing the highest number of quota (five) to NA for conducting National Defense Course (NDC) every year, whereas the India provides only one quota every year to NA for the same course. It costs around Rs. 10 million to NA for sending its one officer to attend and complete the NDC course abroad (Khatri, 2017).

Most importantly, the Nepali Army is one of the vital contributors to the UN peacekeeping missions. Apart from serving in Britain, India and in the UN missions, the Gurkhas of Nepal till this day serve in the Singapore Police as the Gurkha Contingent and in Brunei as the Gurkha Reserve Unit. Today, Nepal's military diplomacy with China may strain Indo-Nepal relations. If China supports Nepal in increasing its presence in $\mathrm{UN}$ peacekeeping missions and continues to assist Nepal in upgrading its security forces while providing training to the military as well as police officials, this may indeed deepen the relationship between the two countries (Amatya, 2018). As of 13 January 2020, the Nepali Army has deployed across 12 missions around the world. As one of the imperative troop contributors, Nepal ranks fifth in the world. Currently, the Nepali Army has around 5095 soldiers, including 170 female armed forces serving in 12 different missions around the globe. Nepal has a commitment to provide up to 5000 peacekeepers should the UN so request (NA Peacekeeping Mission, 2020).

Nepal became a member of the United Nations in 1955 and since then, has been an active participant of most UN peace operations. The participation of the Nepali Army in the UN peace support operations spans a period of over a half century covering some 43 UN missions, in which over 1, 29, 890 personnel have participated. The army's long association with the UN peace support operations began with a modest deployment of five military observers in Lebanon (United Nations Observer Group in Lebanon) in 1958. The first Nepali contingent, Purano 
Gorakh Battalion was deployed in Egypt in 1974. The Nepali Army has contributed to senior appointments at UNDPKO and Force Headquarters while deploying military contingents, military observers and staff officers. The Nepali Army has also rendered tremendous services to the provision of niche capabilities, such as engineers, medical teams and Special Forces contingents. Their devotion to duty and excellent performance have been widely acclaimed. The Nepali Army has always accepted challenges and participated in most difficult operations. This has had a heavy toll on its personnel, and to date, 65 personnel have made the ultimate sacrifice at the altar of world peace and another 66 have been disabled (NA Peacekeeping Mission, 2020).

\section{PARTICIPATIONOFNEPALI ARMYIN UN MISSIONS}

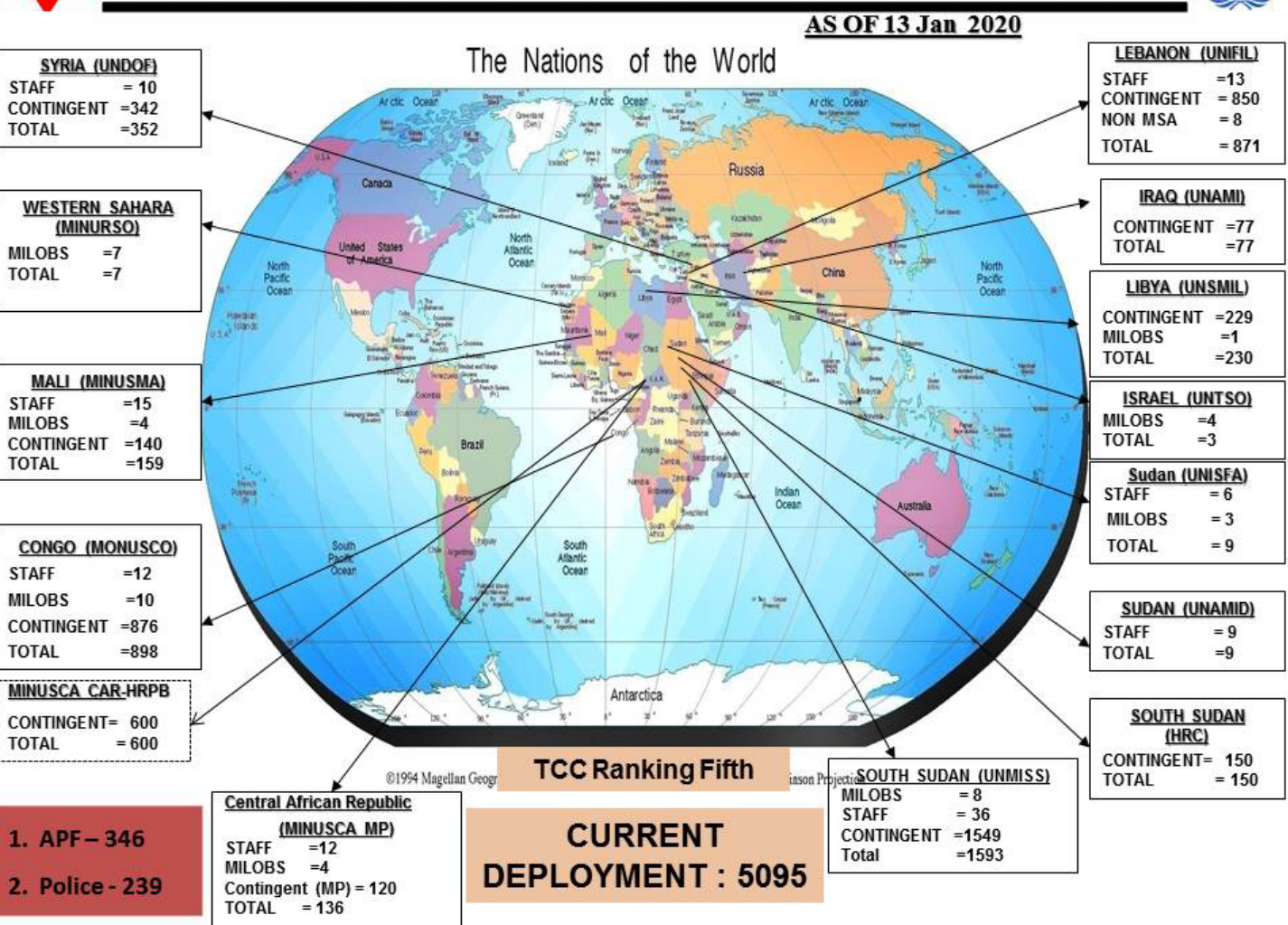

Source: https://www.nepalarmy.mil.np/ 


\section{Conclusion}

Different states use diverse channels of diplomacy. Quintessential and valued to enhance country's image and security, however, is the military diplomacy. Besides safeguarding the national border and shielding the national sovereignty, the modern-day military institutions are exercising diplomacy as well. Thus, when it comes to Nepal's military diplomacy towards the neighborhood and beyond, it's better to acknowledge the fact that Nepali Army has been conducting joint military drills with different countries, most importantly with the United States, India, and China for many years. Essentially, Nepal's vibrant role in exercising the military diplomacy with the great and emerging powers, is immensely triggered by neutrality and non-alignment, which are also the foreign policy objectives of Nepal. Unforgettably, having almost six decades of experience in peacekeeping operations around the world, Nepali Army has effectively enhanced the image of Nepal through the UN Peacekeepers. Thus, it indicates that as one of theoldest institution of the country, Nepali Army has demonstrated its competence to exercise the modern-day diplomacy at the global stage, of course, not being limited to immediate neighborhood.

\section{References}

Adhikari, B. (April 9, 2015). Gurkhas in the Indian mutiny. Spotlight Nepal https://www. spotlightnepal.com/

Amatya, K. (September 25, 2018). Nepal's military diplomacy. The Diplomat. https:// thediplomat.com/2018/09/nepals-militarydiplomacy/

Berridge, G. R. (2002). Diplomacy, theory and practice. New York: Palgrave Macmillan: New York, pp. $2-3$.
Bhattarai, K. D. (May 19, 2019). A brief history of Nepal-China defense ties. Annapurna Express. https://theannapurnaexpress.com/ news/ a-brief-history-of-nepal-china-defenseties- 1560

Clausewitz, C. V. (1976). On War., trans. Michael Howard and Peter Paret. Princeton: Princeton University Press, p. 87.

Jaishankar, D. (January 12, 2017). India's military diplomacy. https://www.brookings.edu/ opinions/indias-military-diplomacy-takingthe-leap/

Khatri, P. (July 7, 2017). Aid keeps relation between NA, foreign army afloat. The Rising Nepal. http://therisingnepal.org.np/news/ 32769

Mulmi, A. R. M. (October 1, 2017). Why did the British not colonize Nepal? Record Nepal. https://www.recordnepal.com/wire/features/ why-did-the-british-not-colonize-nepal

NA Peacekeeping Mission. (2020). The Nepal Army in UN Peace Support Operation. https:// www.nepalarmy.mil.np/

Pajtinka, E. (2016). Military diplomacy and its present functions. Security Dimensions.

Issue 20 (20), p. 1. ISSN: 2353-7000 | ICV: 100,00 MNiSW: 20. https://securitydimensions. publisherspanel.com/resources/html/article/ details?id $=177139$ \&language $=$ en

Thapa, C. (November 11, 2016). Nepal-India relations in the military realm. SouthAsia.com. au. http://www.southasia.com.au/2016/11/11/ nepal-india-relations-military-realm/ 